\title{
Free Trade: A Major Factor in U.S. Farm Income
}

\author{
CLIFTON B. LUTTRELL
}

E XPORTS of U.S. farm commodities totaled $\$ 23$ billion in 1976 and are expected to exceed that amount this year. Exports in the past year accounted for almost 25 percent of the dollar vahe of all farm commodity sales, and the 100 million acres of land utilized in producing this volume of exports represented 30 percent of the total acreage harvested. Thus, exports play a significant role in determining the nation's farm income.

Since 1970 farm exports have increased both in dollar value and as a share of total farm commodity sales. The 1975-76 marketing year was the seventh successive year of record agricultural exports in nominal terms. The $\$ 23$ billion of farm products exported last year was almost four times the dollar value of farm exports in 1969 and more than double the value of 1972 . The nominal value of farm exports rose at a 21 percent annual rate during the seven-year period since 1969, while in real terms (at constant prices) they rose at a 12 percent rate. The value of such exports rose from 14 percent of farm commodity sales in 1970 to 24 percent in 1976. Furthermore, in 1976 a smaller proportion of the exports was sold on concessional terms (aided by Government subsidies). Concessional sales abroad declined from two percent of total farm commodity sales in 1972 to one percent in 1976.

Farm exports as a percent of farm commodity sales have moved in a U-shaped pattern since World War I (see accompanying chart). In the early 1920 s such exports exceeded 20 percent of gross farm receipts. By the late 1920 s farm exports had declined to 17 percent of sales; they averaged 11 percent of sales during the $1930 \mathrm{~s}, 10$ percent in the $1940 \mathrm{~s}$, and 12 percent in the 1950s. In the 1960s exports rose to 15 percent of sales and continued upward in the 1970s, averaging 24 percent of sales in the three calendar years 1974-76 inclusive - almost the same as in the early 1920 s.

\section{RESTRICTIVE NONTD TADE PRACWCES}

The downturn in farm exports in the 1920s can be largely traced to substantial increases in artificial restrictions on world trade in general. The relatively free trade era beginning in the mid-1800s - trade without high tariffs, quotas, and other government restrictions - was generally on the wane following World War I. In the 1920s there was an observable worldwide trend toward increased international trade restrictions. Britain, a traditionally free trade nation, levied the Key industries Duty in 1921 which imposed a 33.33 percent ad valorem tariff rate on many items. In addition, wartime duties were reimposed on a number of "luxuries" in 1925, after their lapse in 1924. The United States enacted the FordneyMcCumber Tariff in 1924 raising import duties on numerous items. Still higher duties were levied by the United States in 1930 with the passing of the Hawley. Smoot Act. This Act authorized tariff rate increases on more than 800 items during the early stages of the great depression. Other nations immediately retaliated by increasing their import duties. ${ }^{\prime}$ Within two years general tariff increases were enacted in nine nations which comprised the major world market for U.S. farm products, including Canada, Cuba, Mexico, France, Italy, Spain, India, Argentina, and Brazil.

As a consequence of these trade restrictions and a worldwide depression, which began in 1929, world trade both in nominal terms and relative to GNP declined sharply. From 1929 to 1932 , the dollar value of world trade dropped 61 percent, and the value of U.S. foreign trade fell 69 percent. ${ }^{2}$ Total U.S, exports

\footnotetext{
IFor a more comprehensive discussion of the impact of the Hawley-Smont Act, sse Allan H. Meltzer, "Monetary and Other Explanations of the Start of the Great Depression," Joumal of Monetary Economics (November 1976), Dp. $459-461$.

-Statistical Yearbook of the League of Nations, 1934-35.
} 


\section{Farm Exports As Percent of Farm Commodity Sales}

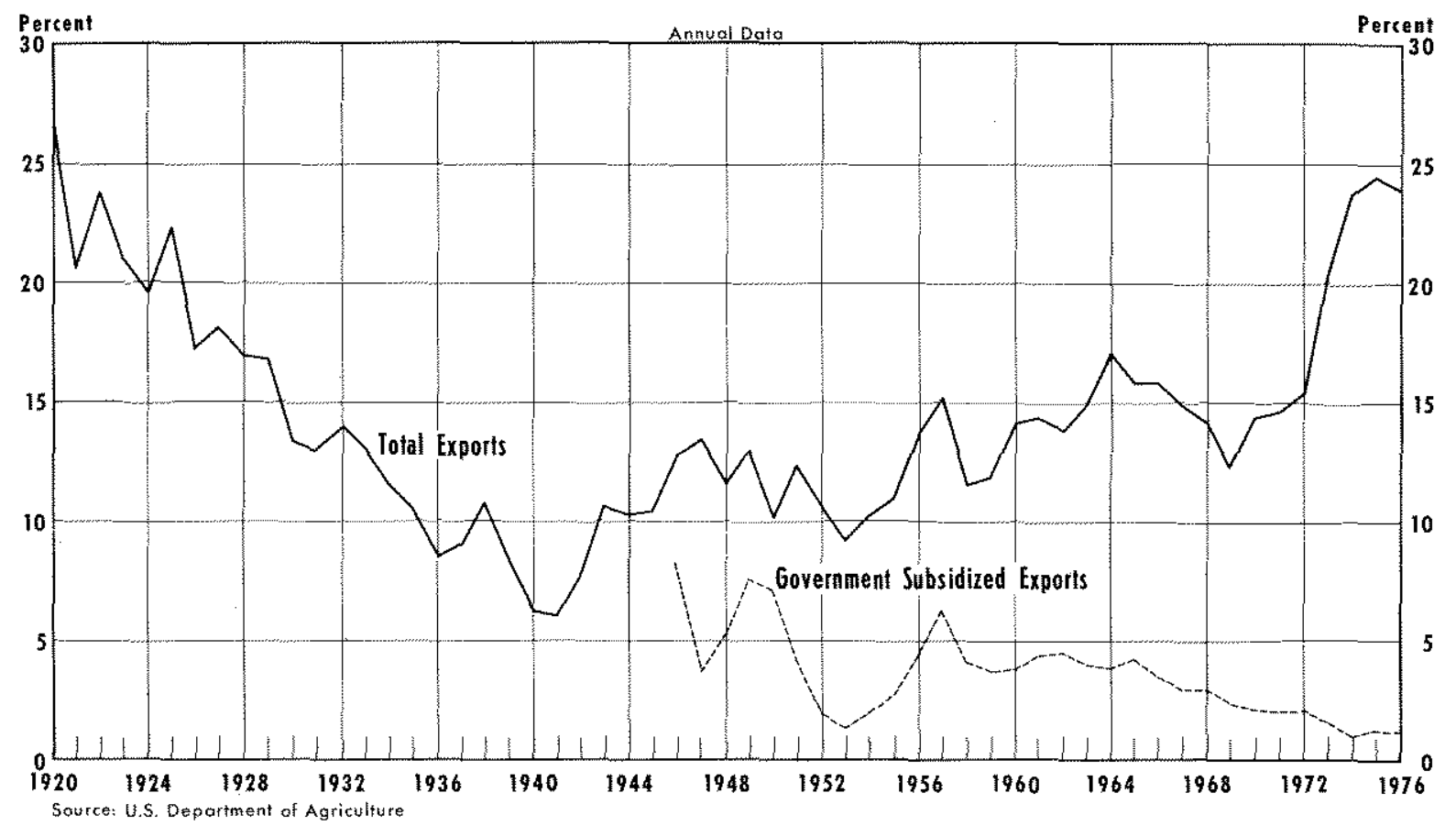

declined from 4.9 percent to 2.7 percent of GNP during the period. Farm commodity exports declined from $\$ 1.8$ billion to $\$ 0.75$ billion during the three fiscal years ending in 1932. Farm exports as a share of total farm production, however, remained relatively stable during the early depression years despite the higher tariff rates. In 1930, the first full year of the depression, farm exports amounted to 13 percent of farm commodity sales, and at the trough of the depression in 1933 such exports, while declining sharply in nominal value, still totaled about 13 percent of sales.

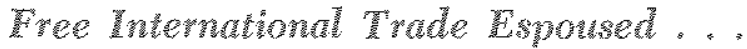

With a new Administration in 1933, the political climate changed, and this nation began to espouse the cause of free international trade. The Hull Reciprocal Trade Agreements Act was passed in 1934, the first of a series of legislative attempts to expand international trade. Other tariff reduction acts and international agreements further contributed to free trade practices. Especially significant were the General Agreement on Tariffs and Trade in 1947 and the Trade Expansion Act of 1962 which authorized the President to negotiate numerous tariff reductions.

While attempts were being made to expand international trade through tariff reductions, Congress en- acted special legistation in a number of instances which was designed to expand farm exports through the use of export subsidies. The expansion of farm exports through the use of Government subsidies was a major factor in the post World War II assistance to Europe and Japan under the United Nations Relief and Rehabilitation Administration, the Marshall Plan, and other relief and recovery programs. A fixed portion of the foreign economic aid funds in 1954 was earmarked to buy surplus farm commodities from the United States. Public Law 480, passed in 1954, was specifically designed to provide a foreign outlet for "surplus" farm products. While these programs were not restrictive within themselves, they tended to produce retaliatory restrictive actions by other nations.

\section{. But hestriche Farm Prograns Enacted}

Despite the stated free trade objectives in the foreign trade legislation and international agreements of the 1930s and the following decades, the major farm programs enacted during this period tended to restrict farm product exports. In 1943 Professor Theodore W. Schultz, in a study of domestic farm programs, pointed out that most of the agricultural agencies established during the 1930s were designed to do one thing - provide "parity" (higher than free- 
market) prices for farm products. ${ }^{3}$ The methods used to attain this objective were supply and production controls, price supports, commodity storage, and surplus disposal programs.

\section{Produchion Controls and price Supports}

In 1933, when the New Deal came into being direct legislative action was taken to increase farm product prices to levels above those dictated by the free market. The Agricultural Adjustment Administration was established to curtal production of most major crops. A specifie number of acres was allocated to the key crops on each farm. Price supports were set through Commodity Credit Corporation (CCC) nonrecourse loans to farmers on stored commodities. The loan and storage programs, financed at taxpayer expense, were designed to guarantee a specific price, usually above the free market level, to farm producers by restricting the flow of commodities to both domestic and export markets. The surplus disposal programs - Public Law 480 , school lunches, food stamps, and other food disposal schemes - were all designed to increase total demand for farm products and thereby enhance prices. The Public Law 480 program, which subsidized exports of farm commodities to the less developed nations, may have increased farm exports somewhat. However, such programs were disruptive of noimal trade flows, and generally have been regarded as "dumping" when used by other nations to export products to the United States.

Production controls and price supports have been a major deterrent to the expansion of intenational trade in farm products over most of the period since the early 1930s. They reduced domestic farm output and led to increased prices for farm products to all users, both domestic and foreign. The average price of U.S. farm products rose at the rate of 15 percent per year from 1932, the last year prior to the programs, to 1935 . In comparison, the average price of industrial commodities rose at a 3.4 percent rate during this period.

Following the production controls and price supports, U.S. farm commodity exports declined both relative to farm commodity sales and as a share of total U.S. exports. Farm exports, which accounted for 14 percent of farm commodity sales in 1932 , dropped to 11 percent of such sales in 1934 following the re. strictions, and continued downward to 8.5 percent in 1936 (see chart). Farm exports averaged 38 percent

Theodore W. Schultz, Redirectum fam Polcy (New York: The Macmilan Company, 1943 ), p. 6. of total U.S. exports during the eight years prior to the programs (1926-33). Farm exports declined to an average of 29 percent of total exports from 1934 to 1940 and to 23 percent of total exports from the end of World War II until 1971, despite the government subsidies on a sizable portion of the farm commodities exported.

The artificially high farm product prices resulting from the production controls and price supports caused the rest of the world to increase the production of farm products from the amounts that would have otherwise been produced. The higher farm product prices increased the returns to resources in agriculture and caused increased resources to move into the industry in the rest of the world. Consequently, farm production outside the United States was enhanced and U.S. farm exports reduced. In addition, increased resources moved into the production of farm commodity substitutes both here and abroad leading to a further reduction in world demand for U.S. farm products.

\section{Cotion}

One prime example of the consequences of the U.S. farm production controls and subsidies was the sharp decline in the usage of domestic cotton. In 1930 , prior to the acreage controls and price supports, this nation supplied more than 50 percent of the world's cotton production. At the beginning of World War II, after seven years of the programs, cotton production in the United States had declined to 40 percent of the world total, and the nation's share contimued down to less than 20 percent of the world total in 1970. In 1930 the United States exported 7.1 million bales of cotton, or more than 50 percent of total world cotton exports. By 1940 U.S. cotton exports had declined to 1.2 million bales or about 15 percent of the world total. The volume of domestic cotton exports rose following World War II, but in 1970 U.S. exports totaled only 3.7 million bales, or 22 percent of the world total.

The cotton programs had a major impact on world land resource use as indicated by shifts in the acreage used for cotton production. During the 1930 s cotton harvested in the United States declined 43 percent, from 42 million to 24 million acres. In contrast, colton harvested in foreign countries rose 24 percent, from 43 million to 53 million acres during the period. In the 40 yeare from 1930 to 1970 , cluring most of which pro-

4U.S. Departinent of Agriculture, Agricultural Statistics, 1972 , p. 698 . 
duction controls and price supports were in effect, acres of cotton harvested in the United States fell 74 percent, whereas the acreage harvested in the rest of the world rose 57 percent. Although part of the reduction in cotton acreage in the United States reflected rising domestic yields and technological developments in the synthetic fiber industry, a large part of the shift can be attributed to the restrictive cotton programs.

While the impact of the cotton restrictions on the use of synthetic fiber substitutes is difficult to assess, the higher prices for cotton resulting from the restrictions were no doubt a factor contributing to the sharp increase in synthetic fiber usage. At the beginning of the controls in 1933, synthetic fiber substitutes were virtually unknown. Following World War II such fibers began to compete aggressively with cotton, and by 1975 the poundage of such fibers used by domestic mills was more than double that of cotton.

\section{Wheat}

Cotton is only one example of export markets being undermined by domestic farm production restrictions and price supports. The wheat acreage controls and price supports had a similar impact. The Government began to hold wheat off the market in mid-1929 through loans to farmers by the Federal Farm Board. In 1933 domestic acreage controls and the International Wheat Agreement further contributed to rising wheat prices and a reduction in wheat exports. While the downward adjustment in domestic wheat acreage was 1 ot as much as was planned during the early years of the controls, because of the drought in 1933 and 1934 , the controls did reduce production, and wheat prices rose. The prices received by farmers rose from an average of $\$ 0.48$ per bushel during the three years $1930-32$ to $\$ 0.82$ during the six years 1934-39. Exports declined from an average of 103 million bushels per year during $1930-32$ to an average of 56 million bushels per year during 1934-39.

The adjustments in resource use in some of the major wheat importing nations as a result of the higher prices took a predictable route. The largest wheat importer, the United Kingdom, increased its wheat acreage by plowing up some grassland and planting it to wheat. Italy expanded her acreage by clearing and draining the Pontine Marshes. France

\footnotetext{
In 1934 Sherman Johnson estimated that the wheat programs had resulted in prices 10 to 15 cents per $13 u s h e$ higher than they otherwise would have been. See wheat Under the Atricaltural Adiutment Act (The Brookings Institution, 1934), p. 90 .
}

made more extensive use of her North African possessions for wheat growing, thereby reducing both domestic wheat production and imports from the United States.

In the United Kingdom wheat prices in 1933 had declined to 67 percent of the 1930 level; they declined further in 1934 but rose sharply in the next three years and during the two years 1937-38 they averaged 51 percent above the 1933 level. The cereal portion of the food price index likewise rose sharply, increasing by 42 percent from 1933 to the average for 1937-38. In contrast to the sharp increase in cereal prices, the meat-fish and other food sectors of the consumer price index rose only 12 and 13 percent, respectively. In response to these changing price relationships British farmers found it profitable to plow up grazing land on which meat was being produced and seed it to wheat. The acreage seeded to wheat rose from 1.34 million in 1932 to 1.92 million in 1938 , an increase of 43 percent. Wheat production in the nation rose 67 percent during the period, and imports of wheat declined. Total wheat and flour imports by the United Kingdom declined 12 percent from the 1931-33 average to the 1937-38 average. ${ }^{6}$

Exports of most other major crops, including feed grains, tobacco, rice and peanuts have likewise been affected by the farm programs, but not to the same extent as wheat and cotton.

The unfavorable impact of the farm price supports and controls on exports was pointed out by Professor Dale Hathaway in 1963 :

Suddenly in the mid-1950's the impact of our domestic programs upon foreign trade in farm products came home to roost with a vengeance. Exports of fam products fell precipitously, aggravating the domestic stocks problem and threatening us with a permanent loss of foreign markets as foreign supplies expancted to fill the gap. ${ }^{7}$

\section{Controls Relared and Exponts Rose}

In recent years Government controls on agriculture have been relaxed. and greater reliance has been placed on free market forces in the use of farm production resources and the pricing of farm commodities. Since the enactment of the Agricultural Act of 1970, most of the domestic farm restrictions have been

\footnotetext{
${ }^{6}$ B. R. Mitchell, Abstract of British Hisforical Stafistics (Cambridge: Cambridge University Press, 1962), p. 99.

Tale E. Hathaway, "Evaluation of Agricultural Programs in Terms of Economic Growth, Forem Trade, and Political Feasibility: A General Appraisal," Increasing Understanding of Pablic programs and Policy Chicago: Farm Foundation, $1969)+73$
} 
redesigned to permit competitive pricing of most crops including wheat, feed grains, the major oilseeds, and cotton. Acreage controls for most crops were largely removed in 1974 with the elimination of the set-aside provisions for cotton, wheat, and feed grains. This action freed about 60 million additional acres for crop production. CCC loans on basic crops have been continued, but the rates have generally been set below world-price levels and subsidies on the production of many farm commodities have been eliminated.

The decline in the impact of the Government pricesupport programs on the price of farm commodities is indicated by the reduced volume of CCC loans and holdings. In 1965 the value of farm commodities owned by the CCC totaled $\$ 4.1$ billion and the corporation had an additional $\$ 2.6$ billion of loans outstanding on farm commodities through price support operations. By 1974 the value of commodities owned by the CCC had declined to $\$ 188$ million, and CCC loans outstanding were down to $\$ 681$ million. The freeing of agriculture from excessive production restrictions and the return to the price mechanism as the major instrument in managing the farm economy has no doubt been a major factor in the sharp increase in farm exports in recent years.

\section{Ohe Factors Contribud to hishg Trmm Enons}

A rising volume of world trade in recent years has contributed to the sharp increase in U.S. farm exports. Since 1970 exports of the eight major commercial nations listed in Table I have increased faster than their Gross National Product (GNP), and in most cases export growth has more than doubled the rate of GNP growth. In contrast, from 1960 to 1964 exports rose at about the same rate as GNP.

In addition to the relaxation of farm programs which has contributed to rising world trade in recent years, other factors affecting the rising volume of farm exports include: a relatively peaceful international situation, the move to more flexible exchange rates, some further tariff reductions, the OPEC oil cartel, and rising real incomes. For centuries the threat of war and the alleged demands for national defense have been used as arguments for greater self sufficiency. The military strength of a nation is believed by many people to be enhanced by self-sufficiency in economic production, particularly food. Consequently, during periods of major threats to world peace and immediately after major international disturbances the proponents of self sufficiency are likely to influ-

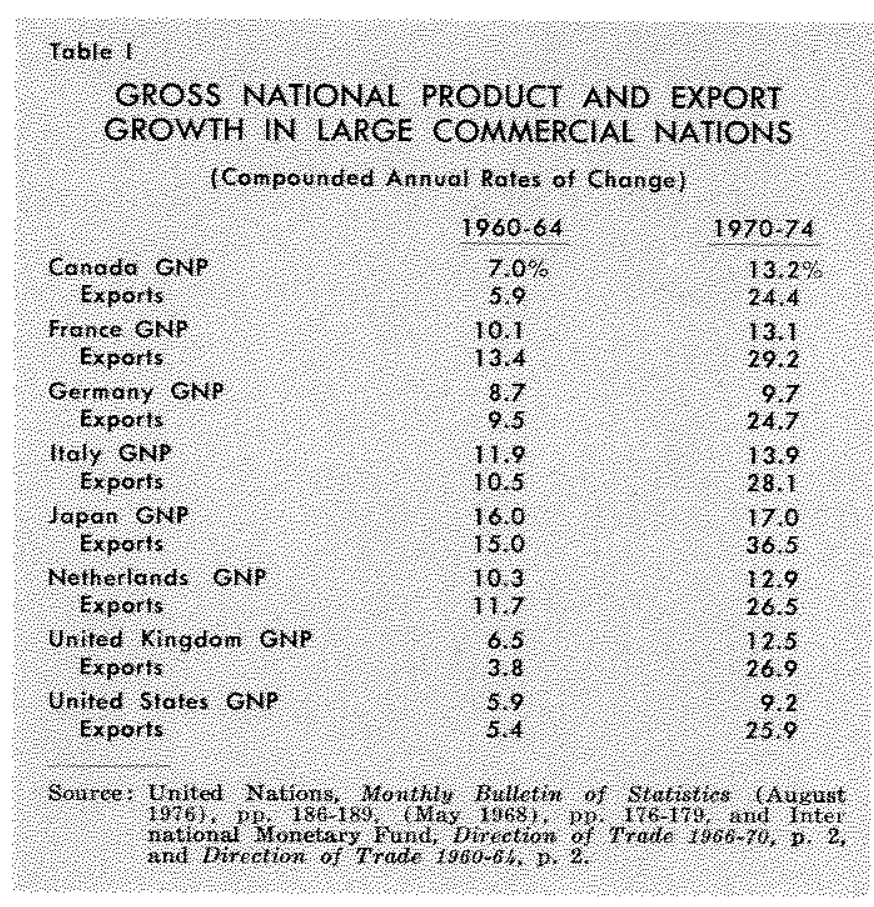

ence national trading policy, especially in those nations which import a large percent of their food supply. These proponents of self sufficiency hold that it is safer in an uncertain world to provide the basic necessities at home even at higher costs. ${ }^{8}$

The move to more flexible exchange rates in 1971 probably contributed to the rise in total international trade by the United States and, thereby, to an increase in farm exports. During the late 1960s the dollar was overvalued in international trade - that is, at the fixed exchange rate American produced goods were less attractive in the international market than foreign produced goods. Consequently, foreign purchases of goods and services from the United States declined relative to foreign sales to the United States. However, with the establishment of the floating exchange rates which emerged from the so-called crisis of 1971 , the dollar was no longer overvalued relative to other currencies and, as a result, U.S. exports of goods and services rose.

While it is argued by some that flexible exchange rates increase the risks of international trade, others point out that the market pricing of currencies leads to a reduction in trade restrictions. Governments often attempt to maintain their currency values by limiting imports and thereby limiting the amount of domestic cumency flowing into international exchange markets. Such restrictions reduce the volume of trade

8Chales P. Kindelberger, Foreign Trade and the National Economy (New Haven: Yale University Press, 1962), 1. 142. 
and the consumption and investment opportunities of the people. Nevertheless, the tendency to restrict trade for purposes of maintaining artificial exchange rates is well entrenched in the political arema." With the demise of fixed rates this reason for erecting trade barriers no longer exists.

Negotiations by the General Agreement on Tariffs and Trade (GATT) members toward further tariff reductions have continued in recent years. In 1973 the members adopted a new Multifiber Textile Agreement which is expected to liberalize and expand world textile trade. The 'Trade Act of 1974 further expanded the President's negotiating authority to reduce tariffs. Also the nation's economy is probably still adjusting to reduced tariff barriers negotiated following the Kennedy round of tariff reductions in the $1960 \mathrm{~s}$. On the other hand, an increasing amount of the trade negotiations in recent years appears to have been negative. The agreements contain numerous safeguards and relief provisions for real or imagined damage to specific industries or labor, and safeguards to national security. Such actions, taken to reverse earlier free trade practices, tend to offset actions intended to further liberalize trade.

While the higher oil prices following the actions of the OPEC cartel cut two ways in the export picture, they probably contributed to increased U.S. farm exports on balance. U.S. oil purchases from abroad have increased several fold since the cartel was formed, and a larger quantity of farm commodities are required to purchase a given quantity of oil. On the negative side, however, a number of the major importers of U.S. farm commodities, such as Japan and Germany, now use a larger portion of their foreign exchange to purchase oil from the OPEC nations. Apparently these nations will have less foreign exchange to purchase farm products from the United States.

\section{Free Trade - A Boon to American \\ Agriculare}

The sharp increase in U.S. exports within the free market setting of recent years reflects a further concentration of resources in those sectors of the nation's economy having the greatest relative advantage. World trade rises as a result of further specialization in resource use. Each trading nation specializes in the production of those commodities in which it has a relative advantage over the rest of the world. Nations

see Gerald M. Meier, Problems of Trade Policy (Oxford University Press, 1973), p. 16. tend to make resource adjustments more nearly in accord with production efficiencies and world markets. World resources move to those uses which will provide maximum returns. Consequently, each nation produces those products in which it has the greatest relative advantage.

The United States has a relative advantage in the production of agricultural commodities. This nation has an abundance of fertile soil, generally favorable weather, and relatively high technological development in agriculture. Consequently, by specializing in agricultural production and trading farm products for the products of other nations, such as petroleum, metals, tropical fruits, coffee, and other imports, we have more goods available for consumption than would be available without the specialization of production and trading. Our increase in farm exports is thus more than matched by a gain in our ability to purchase goods and services produced by other nations. Conversely, the gain in exports to the United States by other nations increases their ability to purchase our farm products and provides them with more goods for consumption. Consequently, any restrictions which dampen our imports or interfere with international trade in any way reduce the degree of mutually profitable international specialization and thereby restrict the export market for domestic farm products.

External world trade and U.S. farm exports can be expected to increase further as the major economies of the world accept freer trade policies. For trade to continue to expand, however, free trade policies are necessary for both exports and imports. Restrictions on imports of foreign goods and services, farm price supports and production controls, and quotas on exports are not conducive to world trade growth. Nations which follow such arbitrary trade restricting practices and production controls cause importing nations to lose confidence in them as a source of supply. Importers will thus become more self suffcient or look elsewhere for a more reliable supply for the same reason that the United States hopes to gain greater self sufficiency in petroleum production and usage. If the United States can avoid such restrictions. our farm exports should continue to expand. Farmers will experience gains from the expansion. Imports of nonfarm products should increase and somewhat slower growth will occur in the domestic production of those types of products that are imported. However, greater expansion will occur in the farm sector and in the farm supply industries such as fertilizer and farm machinery. Hence, the rise in specialization 
and foreign trade will not cause any net loss of jobs or reduce the overall returns to labor and other resources. In contrast, all trading nations should gain from the greater output and consumption resulting from further world specialization of resource use and production.

\section{CONCLUSION}

Since 1970 U.S. farm exports have risen sharply, both in dollar value and relative to total farm commodity sales. Firm exports now account for almost 25 percent of the value of all farm commodity sales, about the same percent as in the early 1920 s - a period of relatively free trade.

During the four decades from 1933 to 1972 , farm exports averaged less than 12 percent of farm commodity sales. During most of this period, farm product prices were maintained above free market levels through Goverument production control and price support programs. These programs limited the expansion of farm exports by raising the costs of such commodities to foreign purchasers. At the higher prices, foreign producers had greater incentive to increase production of these and substitute products. In addi- tion, the support prices contributed to the replacement of cotton by synthetic fibers in both domestic and foreign markets.

With the elimination of most price supports and production controls on farm products in the early $1970 \mathrm{~s}$, farm exports relative to total sales again climbed to about their 1920-30 levels. While a portion of the recent farm export gains can be attributed to reduced tarifs and other factors, such as the move to more flexible exchange rates and a relatively peaceful international scene, part of the gain is attributable to the relaxed domestic price support and production control programs.

If the restrictive farm programs are not reimposed, and free trade practices are maintained, a high percentage of the nation's farm production will probably continue to be exported. This nation has a relative advantage in the production of most farm products and under a free trade regime farm exports will rise. A rising volume of farm exports under free market conditions is beneficial to American farmers and at the same time increases the goods and services available 60 all people in the trading nations. 